\title{
TIFA DI TANAH PAPUA DALAM PERSPEKTIF ETNOMUSIKOLOGI
}

\author{
(Tifa of Papua in Ethnomusicological Perspective)
}

\author{
I Wayan Rai S \\ ISBI Tanah Papua \\ Jalan Raya Sentani, EXPO Waena, Kota Jayapura \\ Pos-el : iwayanrais@gmail.com
}

\begin{tabular}{|c|c|}
\hline INFO ART & $A B S T R A C T$ \\
\hline $\begin{array}{l}\text { Histori Artikel } \\
\text { Diterima : } 25 \text { Juli } 2020 \\
\text { Direvisi : } 30 \text { Oktober } 2020 \\
\text { Disetujui : } 2 \text { November } 2020\end{array}$ & $\begin{array}{l}\text { Tifa is a traditional musical instrument in the Land of Papua. Until now, the study } \\
\text { of Tifa is still very limited, although there are several articles about this } \\
\text { instrument, these writings are still very concise and incomplete. The purpose of this } \\
\text { research is to find out more deeply about the music of Tifa in Tanah Papua. The } \\
\text { tifa is seen as an important musical instrument for the Papuan people that has been }\end{array}$ \\
\hline $\begin{array}{l}\text { Keywords: } \\
\text { Tifa, Papua, } \\
\text { Ethnomusicological, } \\
\text { Context, Musical } \\
\text { Instrument }\end{array}$ & $\begin{array}{l}\text { context of the tifa in the supporting communities in Papua. This research was } \\
\text { conducted using qualitative methods. The data source of this research is the Tifa } \\
\text { music itself, the selected informants include the chiefs of the tribe, the players, and } \\
\text { local cultural observers. All data that has been collected through participatory } \\
\text { observation, interviews, and recordings, were analyzed using music theory and } \\
\text { structural functional theory. Based on the results of data analysis, it can be } \\
\text { concluded that: (1) Tifa is a traditional musical instrument in Papua which is made } \\
\text { of wood with a membrane made of animal skin and is classified as a single-headed } \\
\text { frame drum. The origin of Tifa is closely related to phochlor. The body of Tifa is } \\
\text { decorated with certain motifs according to the beliefs of the people who support it. } \\
\text { This musical instrument is played by a player by hitting part of his membrane on } \\
\text { the basis of four rhythm patterns. (2) In a cultural context, tifa has a function as an } \\
\text { attribute of the greatness of the Ondoafi (tribal chief), as a means of } \\
\text { communication, a means of connecting to God, ancestors, and other natural forces. } \\
\text { As a result of expressive culture, this instrument is used as an accompaniment to } \\
\text { wor songs and a dance accompaniment. The Papuan people interpret tifa as a } \\
\text { cultural work that is used as a symbol of identity, a giver of identity, and a means } \\
\text { of strengthening social ties. }\end{array}$ \\
\hline
\end{tabular}

\section{ABSTRAK}

Tifa adalah salah satu jenis alat musik tradisi di Tanah Papua. Sampai saat ini studi tentang Tifa masih sangat terbatas, walaupun ada beberapa artikel tentang alat musik ini, namun tulisan-tulisan tersebut masih sangat ringkas dan tidak lengkap. Tujuan dari penelitian ini adalah untuk mengetahui secara lebih mendalam tentang musik Tifa di Tanah Papua. Tifa dipandang sebagai instrumen musik penting bagi masyarakat Papua yang telah diwarisi sejak masa yang lampau. Selain itu juga untuk mengetahui konteks sosial-budaya tifa itu pada masyarakat pendukungnya di Tanah Papua. Penelitian ini dilakukan dengan menggunakan metode kualitatif. Sumber data penelitian ini adalah musik Tifa itu sendiri, para informan terpilih antara lain kepala suku, para pemain, dan budayawan daerah setempat. Seluruh data yang telah dikumpulkan melalui observasi partisipasi, wawancara, dan rekaman, dianalisis dengan menggunakan teori musik dan teori fungsional struktural. Berdasarkan hasil analisis data dapat disimpulkan bahwa: (1) Tifa adalah instrumen musik tradisi di Tanah Papua yang terbuat dari kayu dengan membrane dari kulit binatang dan tergolong singleheaded frame drum. Asal usul Tifa terkait erat dengan foklor. Badan Tifa dihiasi dengan motif-motif tertentu sesuai kepercayaan masyarakat pendukungnya Alat musik ini dimainkan oleh seorang pemain dengan jalan memukul bagian membrane nya dengan basis empat pola ritme. (2) Dalam konteks sosisal budaya, tifa memiliki fungsi sebagai atribut kebesaran Ondoafi (kepala suku), sebagai sarana komunikasi, sarana penghubung kepada Tuhan, leluhur, serta kekuatan alam lainnya. Sebagai hasil kebudayaan ekspresif, alat musik ini dipergunakan sebagai pengiring nyanyian wor dan pengiring tari. Masyarakat Papua memaknai tifa sebagai karya budaya yang dijadikan simbol jati diri, pemberi identitas, dan sarana penguat ikatan relasi sosial. 


\section{PENDAHULUAN}

Papua adalah bagian paling timur dari wilayah Negara Kesatuan Republik Indonesia yang berbatasan langsung dengan Papua Nugini (PNG). Papua, yang dikenal pula dengan sebutan Bumi Cenderawasih atau Bumi Matahari Terbit, terbagi menjadi dua provinsi, yaitu: provinsi Papua dengan ibu kota Jayapura, dan provinsi Papua Barat dengan ibu kota Manokwari. Provinsi Papua adalah provinsi induk sedangkan provinsi Papua Barat adalah provinsi pemekaran sejak tahun 2003.

Nama Papua berasal dari pelaut Portugis, ketika pertama kali mereka melihat pulau ini pada tahun 1511 yang kemudian mereka namakan ilhas dos Papuas yang berarti kurang lebih pulau yang dihuni orang berambut halus. Pelaut Belanda kemudian menyebut Papua sebagai New Guinea karena kulit orang Papua yang hitam mengingatkan mereka dengan orang Guinea di Afrika, sedangkan New artinya Baru (Wetipo dan Wedlama, 2015: 1).

Setelah New Guinea, maka pada masa pemerintahan Belanda, Papua dikenal dengan sebutan Dutch Nieuw Guinea; dan ketika wilayah ini menjadi bagian dari Negara Kesatuan Republik Indonesia pada tahun 1963, namanya diubah menjadi Irian Barat, lalu diganti lagi menjadi Irian Jaya. Pada masa pemerintahan Presiden Abdulrahman Wahid nama pulau ini dikembalikan menjadi Papua.
Papua adalah pulau terbesar kedua didunia setelah Greenland, Kanada dengan penduduk termasuk rumpun Melanesia yang memiliki ciri-ciri seperti berkulit hitam, berambut keriting dan berombak, memiliki badan yang kekar dan tinggi (Wetipo dan Wedlama, 2015: 1). Melalui sentuhan dengan dunia luar, terutama terjadinya perkawinan silang, telah menghasilkan keturunan yang memiliki ciri-ciri fisik yang berbeda dengan penduduk asli. Kenyataan itu tampak jelas pada penduduk yang hidupnya didaerah pesisir atau pantai.

Penduduk Papua terdiri atas lebih dari 250 etnik, mereka hidup berkelompok dalam unit-unit kecil, memiliki adat-istiadat, budaya, dan bahasa tersendiri. Karena masing-masing suku memiliki bahasa yang berbeda menyebabkan adanya kesulitan komunikasi antara satu suku dengan suku yang lainnya. Seiring dengan berjalannya waktu dan perubahan yang terjadi, kesulitan berkomunikasi ini secara berangsur-angsur semakin bisa diatasi dengan dipakainya bahasa Indonesia sebagai alat komunikasi antar suku maupun sesama warga Indonesia. Perlu dicatat pula bahwa apabila mereka berkomunikasi dengan sesama warga sukunya, mereka akan tetap berkomunikasi sesuai bahasa lokalnya atau sudah menggunakan bahasa campuran antara bahasa lokal dan bahasa Indonesia logat Papua.

Secara garis besarnya, Papua terbagi 
menjadi tujuh (7) wilayah budaya (wilayah adat) dengan perincian lima (5) terletak di Provinsi Papua dan dua (2) di Provinsi Papua Barat. Kelima wilayah budaya yang terletak di Provinsi Papua, yaitu: wilayah budaya Mamta (Mambramo Tabi), Seireri, La Pago, Mi Pago, dan Anim Ha; sedangkan yang terletak di Provinsi Papua Barat adalah wilayah budaya Bomberei dan Domberei. Setiap wilayah budaya pada umunya memiliki beberapa kesamaan dan keunikan tersendiri sehingga Papua merupakan salah satu wilayah yang memiliki kekayaan seni budaya yang sangat beragam. Satu di antara kekayaan seni budaya itu adalah tifa, sejenis kendang (drum). Di Papua, tifa memiliki nama lokal yang beragam misalnya saja sireb di Biak, dan waku di Sentani.

Sampai saat ini studi tentang tifa masih sangat terbatas, walaupun ada beberapa artikel tentang alat musik ini, namun tulisan-tulisan tersebut masih sangat ringkas dan tidak lengkap. Selain itu, pada era globalisasi dan Revolusi Industri 4.0 ini generasi millenial yang diharapkan sebagai generasi penerus keberlanjutan tifa itu, semakin banyak yang menggandrungi musik pop, baik pop Indonesia maupun pop Barat dan seni virtual lainnya. Oleh karena itu, langkah cepat dan tepat harus segera dilakukan. Kalau tidak, maka dikhawatirkan bahwa pada suatu saat nanti salah satu warisan budaya yang mengandung nilai-nilai luhur budaya bangsa hanya akan tinggal nama.
Penelitian ini adalah sebuah studi tentang tifa di Tanah Papua dalam perspektif etnomusikologi. Menurut Mantle Hood (1970), etnomusikologi adalah sebuah studi tentang musik ditinjau dari segi teks (itself) dan konteks (socio-cultural context). Hood menegaskan bahwa obyek studi dari etnomusikologi adalah musik; musik apa saja, dimana saja, dan kapan saja. Dalam etnomusikologi, teks merupakan studi tentang musik itu sendiri, disebut juga dengan istilah study interms of itself atau study about music; sedangkan konteks merupakan studi tentang hubungan musik dengan aspek sosial budaya masyarakat pendukungnya. Istilah lain yang dipergunakan dalam mengkaji konteks adalah study around music.

Penelitian ini dilakukan dengan menggunakan metode kualitatif. Sumber data penelitian ini adalah musik tifa itu sendiri, para informan terpilih antara lain kepala suku, para pemain, dan budayawan daerah setempat. Seluruh data yang telah dikumpulkan melalui observasi partisipasi, wawancara, dan rekaman, dianalisis dengan menggunakan teori musik dan teori fungsional struktural.

\section{PEMBAHASAN}

\section{Studi tentang Teks (interms of itself)}

Ada enam hal yang dibahas pada bagian ini, yaitu: asal-usul tifa, kajian organologi, ornamen pada tifa, ornamen pada tubuh pemain (body painting), teknik bermain tifa, dan pola ritme. 


\section{Asal-usul Tifa di Tanah Papua}

Asal-usul tifa di Tanah Papua berkaitan erat dengan foklor (tradisi lisan). Setiap suku yang mewarisi Tifa secara turun temurun, memiliki cerita lisan tentang tifa yang dikaitkan dengan mitos tentang sukunya sendiri maupun mitos tentang kedekatan mereka dengan lingkungan alam. Oleh karena itu tidaklah mengherankan apabila didapatkan berbagai versi tentang asal-usul tifa di Tanah Papua. Sebagai produk masyarakat komunal, asal-usul tifa itu adalah anonim dan pewarisan maupun penyebarannya dilakukan dari mulut ke mulut, dari satu generasi ke generasi berikutnya. Pewarisan itu telah berlangsung sejak masa yang lampau hingga sekarang sehingga model pewarisan dan penyebaran seperti itu sangat memungkinkan terjadinya interpolasi (penambahan atau pengurangan). Sebagai sebuah contoh, berikut ini adalah salah satu mitos tentang asal-usul tifa di Biak.

Pada suatu hari, di sebuah kampung di Biak, akan diadakan pesta besar yang akan diikuti oleh semua warga. Seluruh penduduk kampung tampak sangat antusias dalam mempersiapkan pesta tersebut. Namun, di tengah semaraknya persiapan pesta, ada seorang anak yatim piatu tampak kebingungan dan bermuram durja. Dalam hati dia bertanya, apa kiranya yang bisa dia sumbangkan untuk acara pesta tersebut. Sebagai anak yatim piatu, dia sangat miskin, namun sebagai warga masyarakat, dia wajib berpartisipasi sebagaimana halnya masyarakat kampung lainnya.

Dengan langkah yang lunglai, dia pergi ke hutan, lalu duduk dan berteduh di bawah pohon kayu. Sambil menangis dia berdoa kepada leluhurnya agar diberikan jalan keluar sehingga dia tidak menanggung malu dengan warga kampung lainnya. Ketika sedang asyik berdoa, tiba-tiba dia mendengar suara aneh dari atas pohon kayu. Suara itu tidaklah lain suara dari seekor biawak yang sedang memukul-mukul perutnya. Anak yatim itu pun terus berusaha mencari tahu sumber suara tersebut. Melihat ada yang memperhatikan maka biawak itu bertanya kepada anak yatim itu “apa yang sedang kau pikirkan nak?” Anak itu menjawab "nanti akan ada pesta besar di kampung. Saya tak punya apa-apa untuk persembahan". "Oh, kalau begitu, saya akan ikut dengan kamu", kata biawak. Anak itu terdiam sejenak, lalu dia bertanya lagi "kamu kan hanya biawak, bagaimana bisa?” Biawak pun menjawab "bawa kulitku dan ikatkan pada kayu yang dilubangi. Kau mainkan, dan akan mengeluarkan bunyi seperti bunyi yang tadi kau dengar". Anak itu menimpali lagi "wah, kalau begitu, untuk mendapatkan kulitmu, kau kan harus kubunuh? Aku akan menyesal kalau sampai membunuh kamu". "Tidak begitu" jawab biawak dengan tegas. Lalu biawak berkata lagi "ku serahkan diriku padamu. Anakku, cepat bunuh aku, kuliti, dan lepas dagingku". Anak itu semakin penasaran dan kembali bertanya "nanti kalau kulitmu sudah 
lepas, lalu bagaimana lagi?”. Biawak menjawab "kencangkan kulitku pada kayu bersilang, lalu jemur atau asapi kulitku pada tungku para-para (tungku pengasap). Setelah kering, ikatkan pada kayu berlubang yaitu kayu yang telah dimakan rayap. Setelah itu lalu pukul dan terus mainkan".

Sehabis percakapan itu, lalu anak yatim itu melaksanakan semua petunjuk yang diberikan oleh biawak. Kemudian dia pergi ke tempat pesta, meskipun dia tiba paling akhir. Setibanya di tempat pesta, anak itu bernyanyi "aku tak punya apa-apa, hanya ini yang kupunya”. Kalimat itu dinyanyikannya secara berulang-ulang sambil memainkan instrumen yang dia bawa. Masyarakat yang sedang berada di pesta itu pun menjadi gempar karena ada sesuatu yang baru dan belum pernah terjadi sebelumnya. Semua orang yang hadir di pesta mengerumuni anak yatim itu. Salah seorang dari tokoh adat bertanya kepada anak yatim itu "apa yang kau mainkan nak"? Dengan cepat anak itu menjawab "sireb".

Sejak terjadinya peristiwa yang mengejutkan itu, maka sireb (tifa) selalu dimainkan pada acara pesta maupun kegiatan adat lainnya sehingga sampai sekarang tetap menjadi bagian dari tradisi Biak. Masyarakat Biak percaya bahwa tifa itu mengandung kekuatan gaib, munculnya bukanlah suatu hal yang kebetulan, melainkan sudah merupakan kehendak dari leluhur mereka. Demikianlah salah satu versi tentang asal-usul sireb (tifa) di
Biak, sebagaimana dituturkan oleh seniman Biak yaitu Hendrik Baransano dan Alfred Mofu (komunikasi pribadi, 2017).

\section{Kajian Organologi}

Organologi adalah bagian dari etnomusikologi yang memfokuskan kajiannya pada instrumen musik. Menurut Mantle Hood (1982: 124), organologi adalah "the science of musical instruments". Dalam organologi, kajian tentang instrumen musik itu tidak saja menyangkut tentang sejarah dan deskripsi serta klasifikasi instrumen, melainkan harus menyangkut aspek- aspek penting lainnya seperti bahan dan proses pembuatannya, bentuknya, hiasan atau dekorasi yang terdapat pada alat musik itu, teknik permainan, termasuk fungsinya dalam berbagai konteks sosial budaya yang ada.

Kalau dilihat dari bahan pembuatannya, pada umumnya tifa dibuat dari kayu, secara lokal disebut "kayu susu" yang banyak tumbuh di hutan belantara. Karena kayu itu tumbuh di hutan yang termasuk wilayah adat suku tertentu, maka dalam mencari kayu untuk bahan tifa maka sebelum kayu yang dipilih itu ditebang, terlebih dahulu harus mendapat ijin dari ondoafi (kepala suku). Setelah mendapat restu dari ondoafi maka proses pertama adalah menebang kayu, lalu kayu itu dipotong-potong sesuai dengan ukuran tifa yang ingin dibuat, lalu dilubangi. Pada masa yang lampau cara melubangi kayu itu adalah dengan jalan menempatkan batu 
panas yang telah dibakar pada rencana lubang yang dikehendaki sampai tembus dari ujung yang satu ke ujung yang lain. Teknik melubangi kayu seperti ini sekarang telah diganti dengan jalan menggunakan pahat untuk melubangi kayu sehingga proses pembuatannya jauh lebih cepat dan praktis.

Ukuran panjang tifa sangat bervariasi, tergantung dari ukuran tinggi rata-rata dari warga suatu suku. Ukuran Tifa yang terpendek adalah sekitar $60 \mathrm{~cm}$ dan yang terpanjang bisa mencapai lebih dari satu meter. Konon ada tifa dari suku Marind yang hidup di daerah Merauke memiliki ukuran panjang sampai empat (4) meter. Tifa itu kabarnya sekarang disimpan di salah satu museum di Belanda. Kenapa tifa suku Marind bisa begitu panjang? Hal ini tidak terlepas dari bentuk dan ukuran fisik dari orang-orang Marind yang pada umumnya kekar dan tinggi. Meskipun demikian, pada suku Marind masih dapat pula dijumpai tifa dengan ukuran yang pendek, dengan ukuran panjangnya sekitar $60 \mathrm{~cm}$. Tifa dengan ukuran pendek ini biasanya dipergunakan untuk mengiringi tarian, dan kadang-kadang pemain tifa itu ikut menari sambil bermain tifa.

Selain kayu, bahan yang dibutuhkan untuk membuat tifa adalah kulit sebagai membran. Pada umumnya jenis kulit binatang yang dipergunakan adalah kulit biawak atau istilah lokalnya dikenal dengan nama soasoa. Kulit biawak tersebut mula-mula dijemur sampai kering, dikencangkan, dipotong dan dihaluskan, kemudian dipasang pada bagian atas dari tifa, dan diikat dengan tali. Sebelum diikat dengan tali membran itu dilem dengan menggunakan getah pohon lengkuas atau lenggua. Getah lenggua ini pula yang dipergunakan untuk mengencangkan membran dengan jalan menaruh beberapa getah yang telah dibentuk menjadi bulatan kecil-kecil.

Selain kulit biawak (Varanus sp.), pada suku Marweri di Sentani Barat, dapat dijumpai pula bahwa membran yang dipergunakan berasal dari kulit rusa (Cervus $s p$.). Sama halnya dengan kulit biawak, terlebih dahulu kulit rusa itu dikeringkan dan dikencangkan. Bedanya adalah bulu dari rusa itu dibiarkan secara alami pada membran, dan lama-lama bulu itu akan rontok dengan sendirinya apabila tifa itu sering dimainkan. Mengingat bahwa ukuran tifa itu bermacammacam maka suara yang dihasilkan pun akan berbeda-beda pula. Semakin kecil ukuran tifa itu akan menghasilkan suara yang semakin tinggi, sebaliknya semakin panjang dan besar ukuran tifa itu akan menghasilkan suara yang semakin rendah atau besar.

Apabila dilihat dari bahan tifa itu yaitu jenis kayu dan jenis kulit binatang yang dipergunakan, maka akan dapat menjadi indikasi secara geografis Papua, di daerah mana jenis kayu itu dapat tumbuh dan di daerah mana pula jenis binatang itu dapat hidup. Dengan kata lain bahwa kedekatan 
manusia dengan lingkungan alam di Tanah Papua telah melahirkan konsep ekologi budaya yang telah dilakukan secara turun temurun sampai saat ini.

Tifa terdiri atas tiga bagian yaitu: bagian paling atas, dari membran kebawah disebut sinan, bagian tengah disebut snon kbor, bagian yang menyerupai ikat pinggang disebut samfar/sarak, dan bagian paling bawah disebut romawa kasun di Biak, bagian yang paling atas (sinan) dianalogikan dengan orang tua, bagian tengah (snon kbor) dianalogikan dengan remaja, dan bagian paling bawah (romawa kasun) dianalogikan dengan anak-anak (komunikasi pribadi dengan Hendrik Baransano, 2017).

Terdapat variasi dari perbandingan ukuran antara sinan, snon kbor, dan romawa kasun, tergantung kekhasan tifa dari suatu suku. Misalnya, tifa Biak ukuran sinan (bagian paling atas) dibuat paling panjang; sebaliknya tifa dari Kampung Inggros, Jayapura, ukuran romawa kasun (bagian paling bawah) dibuat paling panjang; sedangkan tifa dari suku Marweri, Sentani Barat, ukuran antara sinan, snon kbor, dan romawa kasun dibuat dengan perbandingan ukuran yang sama.

Sesuai dengan klasifikasi instrumen musik Sach-Hornbostel, tifa digolongkan ke dalam klasifikasi membranophone yaitu sebuah alat musik dengan sumber suara berasal dari kulit yang dikencangkan. Secara lebih spesifik lagi, tifa termasuk alat musik perkusi yang disebut single-headed frame drum atau sejenis kendang dengan satu membran.

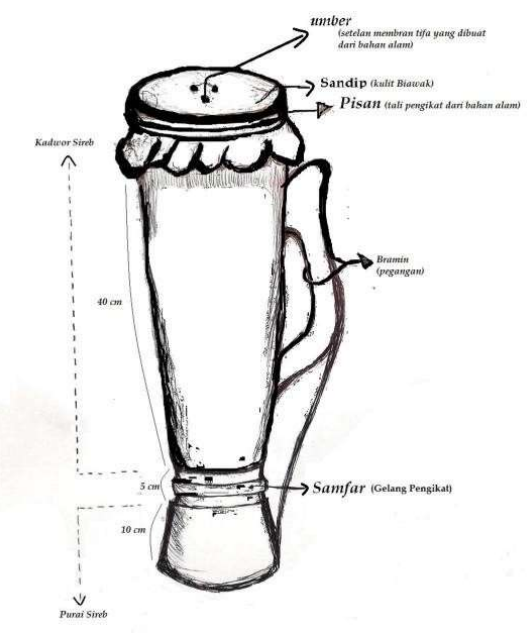

Gambar 1. Ilustrasi Tifa

(Dokumentasi: Hendrik Baransano dan Septina Layan)

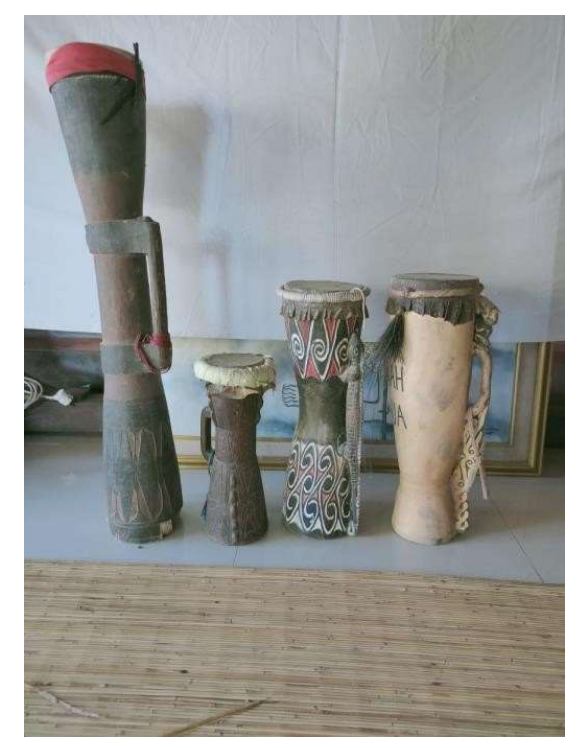

Gambar 2. Tifa Suku Marin, Kampung Enggros Jayapura, Sentani, dan Biak (Dokumentasi; I Wayan Rai S)

\section{Ornamen pada tifa}

Ornamen pada tifa adalah hiasan atau dekorasi pada instrumen tifa itu sendiri. Badan tifa dihiasi dengan ornamen yang beragam, 
ada yang dihiasi secara penuh dan ada pula yang dihiasi hanya pada bagian tertentu saja. Kecendrungan dari ornamen tersebut adalah berupa motif-motif yang dipercaya sangat penting dari suku tertentu. Ornamen itu telah diwarisi secara turun temurun dari nenek moyang mereka, memiliki kekhasan dan keunikan dengan kandungan makna yang sangat dalam.

Tifa Biak biasanya menggunakan motif-motif yang disebut karerin. Dalam karerin digambarkan binatang yang berkaitan dengan kehidupan manusia di Biak, seperti jangkrik dan burung camar, sebab menurut kepercayaan orang Biak hewan-hewan tersebut selalu memberi tanda kepada manusia. Misalnya, kalau jangkrik itu berbunyi, itu menandakan bahwa air laut itu akan surut atau air laut itu akan pasang. Burung camar memberi tanda bahwa di tempat tersebut banyak ikannya sehingga dapat menjadi semacam petunjuk bagi nelayan yang ingin mencari ikan. Selain itu ada pula tifa yang dihiasi dengan ornamen hewan laut seperti gurita, kerang, ikan hiu, dan terumbu karang. Motif-motif tersebut memberi makna bahwa orang Biak itu adalah pelaut yang tangguh dan mereka sangat menghormati alam dan lingkungan. Contoh lain dari Biak adalah tifa yang dibuat seorang seniman bernama Hendrik Baransano. Ornamen dari tifa karya seniman ini ditekankan pada bagian di atas dan di bawah pegangannya. Di atas pegangan diisi dengan hiasan sebuah patung Abai, di bawah pegangan diisi dengan ornamen yang menjalar dan bagian samfar (gelang pengikat) dihiasi dengan ornamen kerang. Karena membran dari tifa ini diambil dari kulit biawak maka dari bagian patung abai sampai ke bagian paling bawah diinterpretasikan sebagai ekor biawak.

Ornamen tifa Kampung Inggros dari Teluk Youtefa, Jayapura menampilkan motif ikan, jaring, dan teluk. Motif itu kadangkadang dibuat secara utuh kadang-kadang tidak. Motif ikan misalnya, yang ditampilkan hanya bagian ekornya saja, motif jaring dibuat menyatu dengan motif teluk. Dari simbol tersebut dapat diketahui bahwa tifa itu adalah berasal dari suku yang hidupnya di pantai dengan mata pencaharian utama menangkap ikan.

Pada suku Marweri yang hidup di Sentani Barat, ornamen pada bagian paling atas dan bagian tengah tifa dihiasi dengan motif kereiapa dan bagian paling bawah dengan motif yotase. Ornamen tersebut adalah ornamen khas suku Merweri yang menggambarkan keperkasaan kepala suku. Pegangan tifa dibuat dengan bentuk buaya dengan bagian kepala menghadap ke atas. Menurut penjelasan ondoafi Marweri yaitu k Adolf Marweri, penggunaan simbol buaya pada pegangan tifa erat kaitannya dengan kepercayaan bahwa buaya itu adalah saudara dari suku Marweri karena dilahirkan oleh nenek moyang mereka. Penggunaan simbol 
buaya pada pegangan tifa dipercaya bahwa roh dari saudaranya itu akan selalu melindungi keturunan suku Marweri. Karena buaya itu dipandang sebagai bagian dari keluarga Marweri maka sampai sekarang suku Marweri dilarang memakan daging buaya (komunikasi pribadi dengan Olof Marweri, Oktober 2017).

Pada suku Sentani yang hidup di Sentani Timur, bagian bawah tifa dihiasi dengan simbol kemaluan wanita dan dua indung telur. Simbol ini menunjukkan bahwa suku Sentani itu sangat menghormati ibu sebab ibulah yang melahirkan, memberi susu, dan mengarahkan hidup mereka. Penggunaan simbol ibu pada ornamen tifa dipercaya juga bahwa roh para leluhur ikut menyertai dan melindungi keturunan suku Sentani. Oleh karena adanya simbol ibu pada ornamen tifa, maka para wanita dilarang untuk memainkan tifa. Menurut penjelasan seorang Abhu Afaa (penasehat ondoafi) Kampung Waena, Sentani yang bernama Levinus Pilemon Modouw, sampai sekarang para wanita tidak diperkenankan dan tidak berani memainkan tifa khususnya tifa yang disakralkan. Konon pernah ada yang melanggar, namun akibatnya sangat fatal pada orang yang bersangkutan. Misalnya, perjalanan hidup wanita itu selalu dirundung malapetaka seperti tidak mendapat jodoh yang baik, tingkah lakunya seperti orang gila, sering stres, menderita sakit keras, bahkan ada yang sampai menemui ajalnya (komunikasi pribadi dengan Levinus Pilemon Modouw, Oktober 2017).
Ornamen pada tifa bisa dibuat tanpa warna atau memakai warna. Apabila ornamen itu diberi warna maka ada tiga warna yang lazim dipergunakan yaitu: warna merah, putih, dan hitam. Ketiga warna itu dipandang sebagai warna dasar Papua. Warna merah melambangkan keberanian, warna putih melambangkan kesucian, dan warna hitam melambangkan kekuatan, ketangkasan, dan dihubungkan dengan kekuatan magis. Kalau ada jenis warna lain yang ditambahkan pada ornamen, maka hal itu hanyalah sebagai bagian dari estetika.

\section{Ornamen pada Tubuh Pemain Tifa (Body painting)}

Selain ornamen pada tifa, maka para pemain tifa pun badannya dihiasi dengan ornamen, sejenis body painting yang kini dikenal secara luas. Ornamen pada tubuh pemain tifa diambil dari simbol-simbol suatu suku, marga, maupun ondoafi (kepala suku). Menurut penjelasan bapak Erick Rumbrawer, seorang seniman Biak, bahwa ketika dia menghias pemain tifa, simbol yang dia pakai berasal dari dua wilayah budaya yaitu dari Seireri dan Tabi (bagian dari Mamta). Ada dua motif dari Seireri yang biasa dia pakai yaitu: manbewor dan mampenas. Manbewor adalah ornamen yang merupakan simbol orang yang pintar dalam menciptakan syair dan lagu wor; sedangkan mampenas adalah ornamen yang melukiskan tumbuh-tumbuhan yang menjalar seperti paku dan anggrek. Selanjutnya dari Tabi dipakai dua motif yaitu yoniki dan katak. 
Yoniki adalah simbol dari marga dan ondoafi tertentu yang tidak boleh dipakai oleh marga atau ondoafi yang lain; sedangkan katak adalah simbol kesuburan (komunikasi pribadi dengan Erick Rumbrawer, Oktober 2017).

Ketika merias pemain tifa, bagian wajah pemain dihiasi dengan ornamen pusaran air dan titik-titik putih. Ornamen ini melambangkan seseorang yang berwibawa dan terkadang bisa sangat berbahaya bagaikan air yang sedang berputar ditengah lautan. Pada dagu diberi hiasan berupa tiga garis putih yang menggambarkan bahwa apa yang dilakukan oleh pemain tifa merupakan sebuah tugas yang suci.

Pada bagian dada dan perut, ornamen yang dipergunakan disebut manbewor, sebuah ornamen yang menggambarkan orang yang pintar dalam menciptakan syair dan lagu Wor. Warna dasar yang dipergunakan adalah putih dilapisi dengan warna merah dan hitam.

Ornamen pada bagian punggung juga manbewor, tetapi di tengahnya diisi dengan ornamen anak panah. Anak panah menggambarkan bahwa dia adalah seorang yang gagah berani dan siap melindungi warganya dari serangan musuh. Pada kedua tangan pemain dihiasi dengan ornamen tumbuh-tumbuhan yang menjalar dan bergerombol yang bernama mampenas yang berasal dari wilayah budaya Seireri.

Pada bagian kaki dihiasi dengan motif yoniki yang merupakan simbol dari ondoafi atau marga tertentu. Simbol ini memberi indikasi bahwa pemain tifa itu memiliki kewibawaan dan kekuatan bagaikan seorang kepala suku atau ondoafi. Yoniki ini sering pula ditambahkan goresan lain, namun fungsinya hanya sebagai penambah keindahan (estetika).

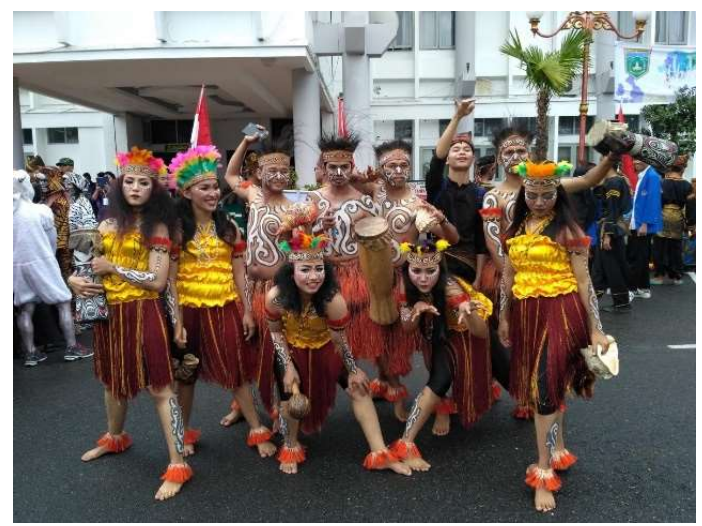

Gambar 3. Tifa (Dokumentasi: I Wayan Rai S)

\section{Teknik Bermain Tifa}

Cara memainkan tifa adalah pertamatama pemain itu memegang instrumen pada pegangan yang ada dengan tangan kiri, dengan posisi sandip (membran) menghadap ke atas. Membran dipukul dengan tangan kanan, posisi telapak tangan kanan tepat di atas lingkaran luar membran sehingga pada saat bermain membran itu dipukul dengan bagian depan telapak tangan dan empat jari tangan kecuali ibu jari. Kadang-kadang bisa juga dimainkan dengan menggunakan ke lima jari tangan, tergantung dari kualitas suara tifa yang dimainkan. Apabila tifa itu dipakai untuk mengiringi tarian, maka permainan tifa itu akan dibuat bervariasi sesuai dengan gerakan pemain tifa itu sendiri. Sebagaimana disampaikan di muka bahwa besar kecilnya suara tifa akan ditentukan oleh besar kecilnya 
instrumen. Oleh karena itu, apabila dalam suatu pementasan dipergunakan beberapa buah tifa maka hasilnya adalah suara tifa yang bervariasi pula.

\section{Pola Ritme}

Sebagai sebuah instrumen perkusi maka salah satu bagian terpenting yang harus dikuasai seorang pemain tifa adalah pola ritmenya. Instrumen musik ini memiliki empat (4) pola ritme dasar yang digunakan dalam bermain, yang saya sebut pola ritme satu (1), pola ritme dua (2), pola ritme tiga (3), dan pola ritme empat (4). Pada waktu bermain tifa, setiap pemain akan memegang satu buah instrumen dan mereka dapat memilih satu diantara ke empat ritme itu atau mereka berimprovisasi sesuai dengan kebutuhan dalam mengiringi suatu tarian atau lagu tertentu. Tergantung dari kemampuan seorang pemain, selain berbasis pada keempat ritme pokok di atas, mereka sering juga bermain improvisasi dengan ritme tertentu secara tepat dan jelas.

Notasi musik di bawah ini adalah pola ritme dasar dari pola satu sampai empat.

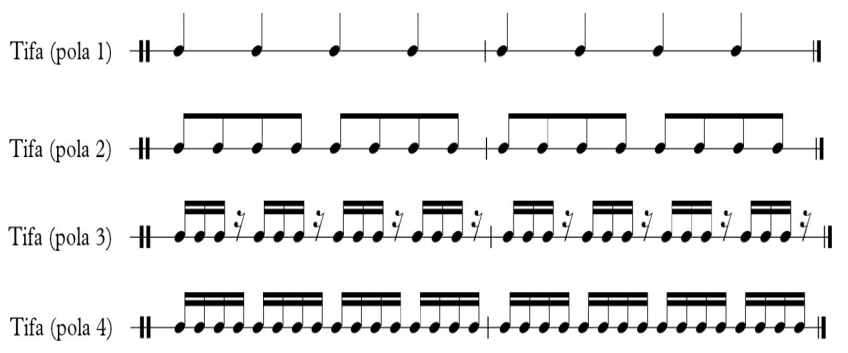

Gambar 4. Notasi musik pola ritme dasar

\section{KONTEKS (interms of its socio- cultural context)}

Pembicaraan tentang konteks, akan diawali dengan pertanyaan "kenapa mereka bermain Tifa"?, dan "apa hakikat bermain Tifa bagi masyarakat Papua"? Untuk menjawab pertanyaan yang pertama yaitu "kenapa mereka bermain tifa"? maka akan saya awali dengan sebuah ungkapan tradisional yang berbunyi "tifa adalah bagian dari kebudayaan Papua. Kalau tidak ada suara tifa, itu berarti tidak ada kehidupan" (komunikasi pribadi dengan Theo Yepesse, April 2017). Ungkapan tersebut mengandung makna yang sangat dalam. Bagi masyarakat Papua, tifa tidak bisa dipisahkan dengan hidup dan kehidupan mereka. Tifa adalah warisan budaya leluhur yang mengandung kekuatan magis serta sebagai media untuk berkomunikasi dengan Tuhan, roh leluhur, para Dewa, Dewi, serta kekuatan alam lainnya. Tifa bukanlah sekedar instrumen musik yang hanya difungsikan untuk ekspresi estetis belaka, melainkan dipandang sebagai instrumen sakral yang dapat melindungi masyarakat serta dipandang sebagai pemberi identitas dan jati diri orang Papua. Karena tifa itu dipandang sebagai pemberi identitas dan simbol jati diri orang Papua, maka tidaklah mengherankan jika kita jumpai patung, ornamen, relief, maupun lukisan tifa dipasang pada bangunan dan tempat-tempat strategis di Tanah Papua. Sebagai sebuah contoh, apabila seseorang yang berkunjung ke Papua melalui Bandara 
Sentani, maka sejak mendarat di airport dan sepanjang perjalanan menuju kota Jayapura misalnya, akan dapat disaksikan bagaimana tifa itu benar-benar sebagai identitas Papua.

Selanjutnya, untuk menjawab pertanyaan yang ke dua yaitu apa hakikat bermain Tifa bagi masyarakat Papua? maka akan dilihat mulai dari pandangan masyarakat Papua tentang seni dan hakikat berkesenian.

Dalam pandangan dan pemahaman Papua-Melanesia, Seni adalah kebenaran, dan kebenaran itu adalah etika moral. Kebenaran dalam batin bahwa itu adalah kedamaian, kepuasan, pemaafan, kearifan yang terlaksanakan dan berbagai aspek rasa hati yang lainnya. Dengan singkat tetapi padat dikatakan, etika dengan demikian adalah kasih, setia dan jujur (Flassy, 2016: 3). Sesuai dengan pandangan itu, hakikat berkesenian bagi masyarakat Papua adalah jalan menuju kebenaran sebab diyakini seni itu adalah kebenaran. Sebagai bagian dari seni budaya Papua, tifa mengandung nilai-nilai luhur yang telah diwariskan sejak masa yang lampu sebagai pegangan hidup. Nilai-nilai luhur yang terkandung dalam tifa itu telah dianut dan membudaya pada masyarakat Papua.

Ungkapan tradisi terkait dengan tifa di atas, masih dipertajam lagi oleh ungkapan tradisi lainnya yang berbunyi "Nggo Wor Baido Na Nggo Mar". Ungkapan dalam bahasa Biak ini berarti "Kalau tidak menyanyi dan menari, kami akan mati". Kata "mati" dalam ungkapan ini bukanlah semata-mata dimaksudkan mati secara badan kasar saja, melainkan "mati" jiwanya. Kalau jiwanya sudah mati tentu seseorang tidak akan bisa melakukan aktivitas secara normal sesuai tradisi yang telah membudaya di Tanah Papua.

\section{Tifa dalam Nyanyian Tradisi $W o r$}

Wor mempunyai dua arti, yaitu: (1) Upacara adat atau pesta adat, dan (2) Nyanyian adat (Kapissa, 1994: 11-12). Dalam nyanyian tradisi wor, Tifa digunakan sebagai sebagai pengiring nyanyian. Sambil menyanyi para pelantun akan memainkan Tifa sekaligus.

Tifa itu akan dibunyikan setelah salah seorang pelanntun menyanyikan bagian kadwor dan fuar sampai selesai. Kadwor adalah bagian depan lagu dan fuar adalah bagian pengulangan dari kadwor yang berfungsi memperjelas makna kadwor. Setelah bagian kadwor dan fuar dinyanyikan, selanjutnya tifa dibunyikan dengan tempo lambat dan dengan satu ketukan atau pukulan. Sementara itu pengulangan nyanyian terus bersahut sahutan dan berlangsung dinamis sampai pada tempo cepat dengan pola permainan Tifa berubah menjadi cepat. Gerakan badan para pelantun nyanyian wor bergerak dinamis mengikuti nyanyian (komunikasi pribadi dengan Hendrik Baransano dan Septina Layan, Oktober 2019).

Di bawah ini adalah contoh lagu wor yang berjudul Kankarem dan Kankarem Yei Wo Papua. Lagu pertama dinotasi dengan notasi angka dan tanpa notasi tifa; sedangkan 
Kankarem Yei Wo Papua dinotasi dengan notasi balok dilengkapi notasi pukulan tifa. Lagu Kankarem ini adalah nyanyian pembukaan pada setiap upacara pesta adat Biak. Syair lagu Kankarem ini mengandung arti bahwa Papua itu negeri atau tanah yang kemiskinan sejak matahari terbit sampai terbenam.

Yei wo Nyaworo Bara

Ori syun robe robe robe yae

Yai wa Papua Wole nyaworo bara Ori syun robe robe robe yae.

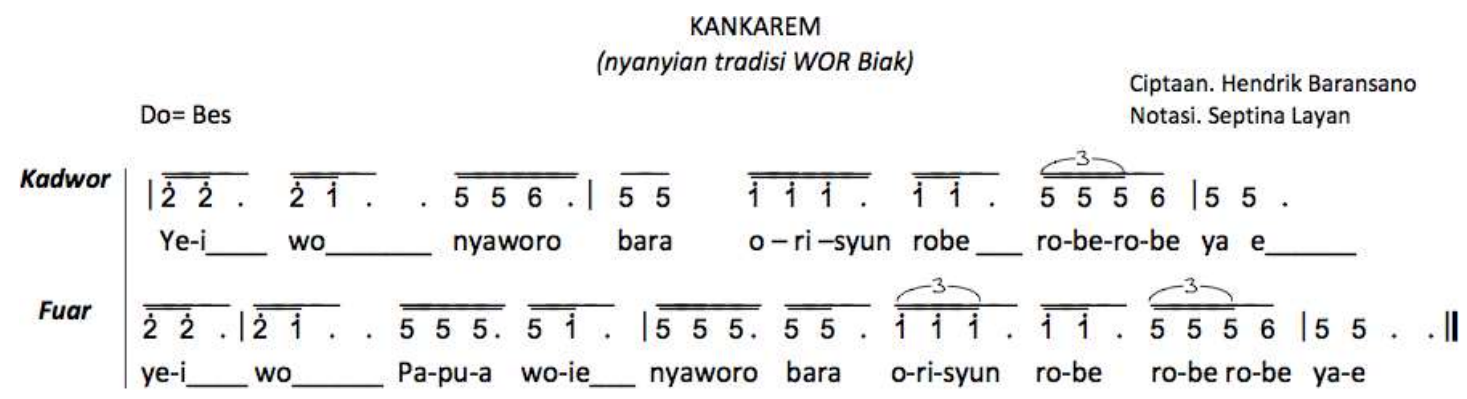

Kankarem Yei Wo Papua

(nyanyian tradisi WOR Biak)
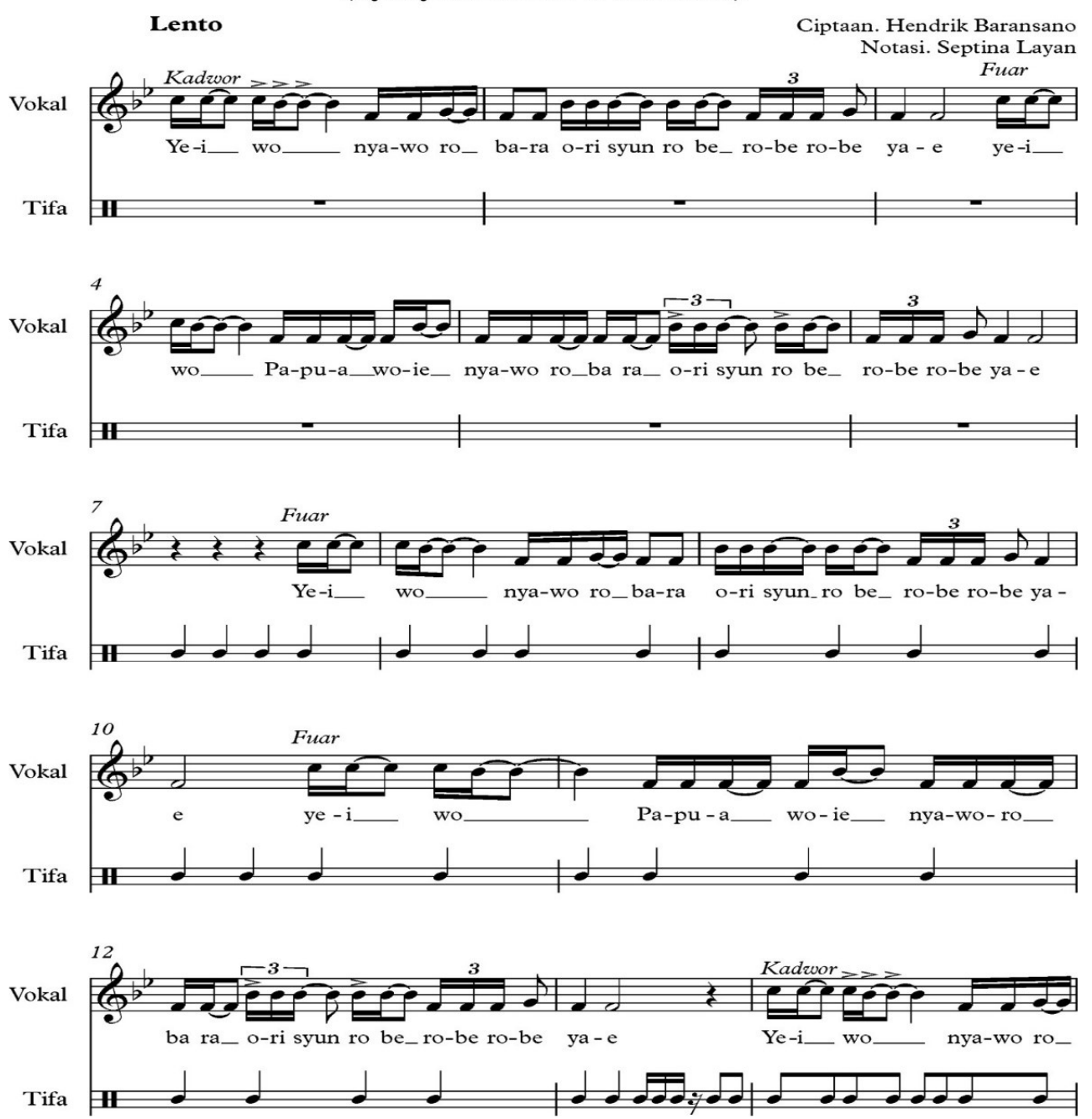

kaya raya, tetapi manusianya hidup dalam 

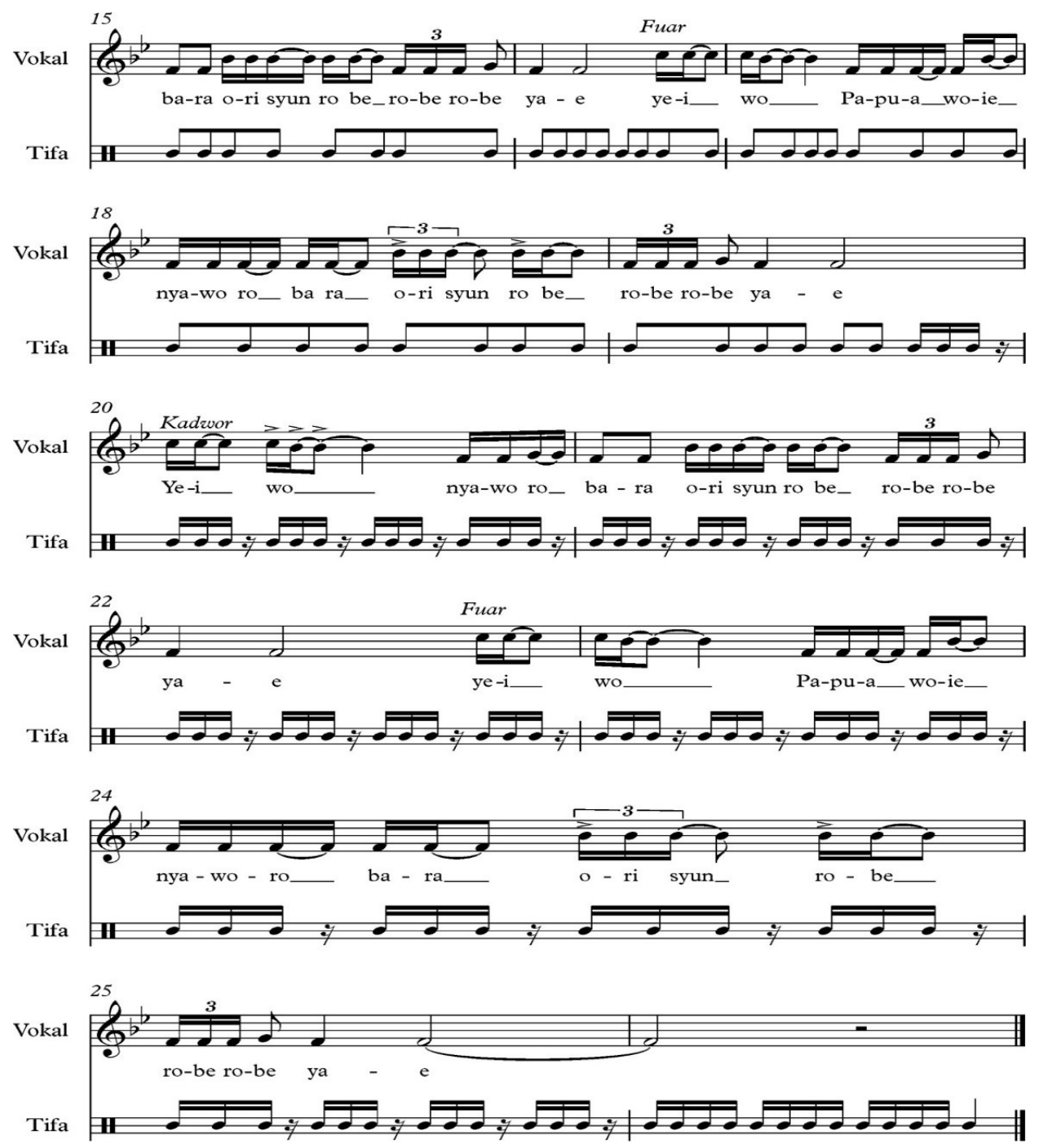

Gambar 5. Not Balok nyanyian tradisi Wor Biak

\section{Konteks Adat}

Masyarakat Papua memiliki adatistiadat yang sangat kuat yang telah berlangsung sejak masa lampau. Sesuai yang di uraikan di depan, bahwa dalam kaitannya dengan adat, Tifa merupakan bagian penting dan tidak bisa dipisahkan. Tifa merupakan salah satu dari lima atribut yang harus dimiliki seorang ondoafi. Kelima atribut itu adalah: noken, tombak, tifa, burung cenderawasih, dan pelataran. Noken adalah simbol tempat penyimpanan harta kekayaan; tombak adalah simbol keperkasaan; tifa simbol dari media komunikasi dan iringan tari; cendrawasih adalah simbol mahkota; dan pelataran adalah tempat untuk melaksanakan kegiatan adat (komunikasi pribadi dengan Theo Yeppese, Maret 2017).

Sebagai instrumen yang disakralkan, tifa disimpan di rumah adat yang bernama obhe dan hanya dimainkan dalam konteks kegiatan adat. Tifa dipercaya memiliki kekuatan gaib, sebagai sarana untuk mengumpulkan masyarakat dan sebagai media untuk berhubungan dengan roh leluhur atau kekuatan alam lainnya. Apabila tifa itu 
dibunyikan oleh salah seorang yang telah ditugaskan oleh ondoafi, maka dengan segera masyarakat tahu bahwa ada kegiatan yang diperintahkan oleh kepala suku mereka. Suara tifa tersebut merupakan sebuah sistem komunikasi, meliputi suara yang telah terstruktur dihasilkan atau ditata oleh anggota masyarakat (seniman) dalam suatu masyarakat tertentu. Suara tifa dengan struktur dan ritme tertentu itu dengan segera dapat dipahami oleh masyarakat pendukungnya karena telah mentradisi dan membudaya. Dalam konteks musik menurut Anthony Seeger dalam Myers (1992: 89) menyebutnya sebagai “ humanly organized sound" sebab menyangkut suara Tifa dan manusia yang menata suara tersebut sehingga terstruktur. Dalam hubungan ini, suara Tifa itu menjadi sebuah sistem budaya (sound as a cultural system) yaitu sebuah sistem simbol dari masyarakat Tanah Papua pada umumnya (Feld, 1990: 3).

\section{Tifa Sebagai Ornamen di Pura Agung Surya Bhuvana, Jayapura}

Pura Agung Surya Bhuvana, Jayapura adalah salah satu dari 36 pura yang kini tersebar di Provinsi Papua dan Papua Barat. Pura Agung Surya Bhuvana telah dirintis pendiriannya sejak tahun 1970-an, kini telah ditetapkan sebagai Padma Bhuana Indonesia Timur. Pura ini terletak di daerah Skyland, Kota Jayapura.

Di Pura Agung Surya Bhuvana ini, penyangga papan nama Pura dibuat berbentuk tifa. Selanjutnya ornamen tifa dapat dijumpai pada relief yang terdapat pada tembok penyengker pura. Uniknya, tembok penyengker pura yang memakai gaya Bali dihiasi dengan ornamen episode cerita Tantri dimana dalam relief itu diisi pula dengan ornamen tifa. Misalnya, salah satu relief Tantri yang mengambil episode perkelahian antara singa dengan lembu, diisi pula ornamen tifa, padahal tifa itu tidak ada disebutkan dalam cerita aslinya. Demikian seterusnya, pada setiap episode cerita Tantri yang digambarkan selalu ditambahkan instrumen tifa, baik tifa secara mandiri maupun tifa dengan burung Cenderawasih. Tifa adalah sebuah instrumen sakral bagi masyarakat Papua, sedangkan burung Cenderawasih juga sangat dihormati karena dianggap burung surga yang dikenal dengan nama bird of paradise. Relief tifa di Pura Agung Surya Bhuvana dapat pula disaksikan pada balai wantilan pura, misalnya pada bagian depan wantilan, bagian depan panggung, serta ornamen pada tiang penyangga wantilan. Ornamen pada wantilan, merupakan perpaduan ornamen gaya Bali dengan gaya Sentani Papua.

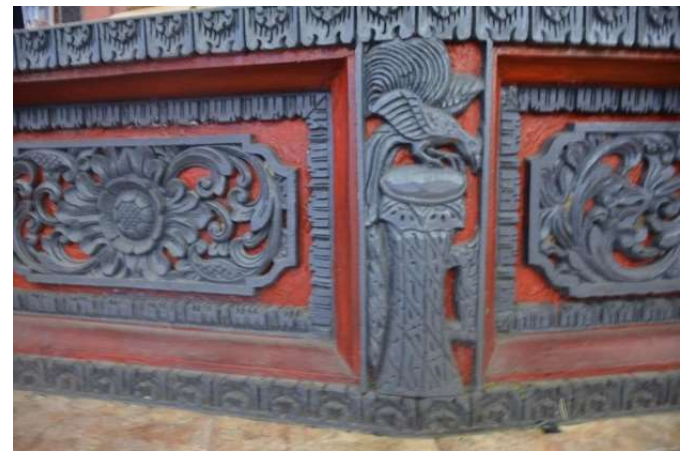

Gambar Tifa di Pura Agung Surya Bhuvana (Dokumentasi: I Wayan Rai S) 
Kenapa tifa digunakan sebagai relief di Pura Agung Surya Bhuvana, Jayapura? Menurut penjelasan dari pemangku gede dan tokoh-tokoh umat Hindu di Jayapura, bahwa pemakaian tifa sebagai relief pura dimaksudkan sebagai bentuk penghormatan umat Hindu kepada kepercayaan dan kearifan lokal masyarakat Papua. Dalam kaitannya dengan pendirian Pura baru di suatu tempat atau daerah, hendaknya dapat dilakukan dengan fleksibel tanpa mengurangi substansinya sebagai tempat suci. Pendirian pura itu dianalogikan bagaikan aliran Sungai Gangga yaitu ketika air Sungai Gangga itu mengalir ke anak sungai maka air itu selalu akan menyesuaikan dengan tempatnya yang baru. Konsep desa, kala, patra (tempat, waktu, dan keadaan) juga dijadikan pertimbangan penting. Dalam hubungan inilah dapat dilihat bagaimana tifa itu menjadi sebuah sarana penguatan ikatan relasi sosial.

\section{PENUTUP}

Tifa adalah salah satu jenis alat musik tradisi di Tanah Papua. Instrumen musik ini tergolong ke dalam klasifikasi membranophone yaitu sebuah alat musik dengan sumber suara yang berasal dari kulit yang dikencangkan. Secara lebih spesifik, tifa termasuk alat musik perkusi yang disebut single-headed frame drum.
Asal-usul tifa itu berkaitan erat dengan tradisi lisan yaitu foklor. Setiap suku di Tanah Papua memiliki cerita lisan tersendiri yang dikaitkan dengan mitos tentang sukunya sendiri, sehingga didapatkan berbagai versi tentang asal-usul tifa tersebut. Karena penyebaran dan pewarisannya dilakukan dari mulut ke mulut dan dari satu generasi ke generasi berikutnya, maka tidak tertutup kemungkinan terjadinya interpolasi. Badan tifa dilengkapi dengan ornamen yang memiliki makna yang sangat dalam.

Tifa adalah instrumen yang sangat disakralkan masyarakat pendukungnya sebab instrumen itu mengandung simbol-simbol penting dari suku tertentu,. Fungsi tifa adalah sebagai simbol kebesaran Ondoafi, sebagai sarana komunikasi, media komunikasi dengan Tuhan, leluhur, serta kekuatan alam lainnya dan sebagai iringan tari. Bagi masyarakat Papua, tifa juga dipandang sebagai pemberi identitas dan jati diri yang telah membudaya. Pada jaman kesejagatan ini, tifa dapat berfungsi sebagai sarana penguatan ikatan relasi sosial. 


\section{DAFTAR PUSTAKA}

Althen, Gary (ed.). 1993. Learning Across Cultures. Iowa City: NAFSA.

Banundi, Roberto dan Bernard Banundi. 2014. Asal Usul, Silsilah Keturunan dan Struktur Kelembagaan Adat Suku Moi-Munggei yang Mendiami Lembah Depau (Kampung Maribu). Jayapura: ARIKA Offset.

Crossly-Holand, Peter. 1982. Musical Instruments in Tibetan: Legend and Foklore. Los Angeles, California: Program in Ethnomusicology, Dept. Of Music, UCLA.

Danandjaja, James. 1986. Foklor Indonesia: ilmu gosip, dongeng, dan lain-lain (2nd ed.). Jakarta: Pustaka Grafitipers.

Dharmojo. Sistem Simbol Dalam Manuba Waropen Papua. Jakarta: Pusat Bahasa, Departemen Pendidikan Nasional.

Ebin, Victoria. 1979. The Body Decorated. London: Blacker Calmann Cooper Ltd.

Feld, Steven. 1990. Sound and Sentimen: Birds, Weeping, Poetics, and Song in Kaluli Expression (2nd). Philadelphia: University of Pennsylvania Press.

Griapon. Alexander Leonard, dkk. 2010. Cerita Rakyat Papua dari Jayapura. Jayapura: Penerbit Arika dan Pemkab Jayapura.

Griapon, Alexander Leonard, dkk. 2012. Cerita Rakyat Papua dari Jayapura: Untuk Generasi yang Sedang Terhempas Dalam Goncangan Peradaban. Jayapura: Penerbit Arika dan Pemkab Jayapura.

Hall, Edward T., and Mildred Reed Hall. 1990. Understanding Cultural Differences. Boston: Intercultural Press.

Hood, Mantle. 1982. The Ethnomusicologist. Ohio: Kent State University Press.

Jones, Stephen. Folk Music of China: Living Instrumental Traditions. New York: Oxford University Press.

Kunst, Jaap. 1968. Hindu-Javanese Musical Instruments. The Hague: Martinus Nijhoff.

Liliweri, Alo. 2007. Makna Budaya dalam Komunikasi Antarbudaya (2nd). Yogyakarta: LkiS.

Merriam, Allan P. 1964. The Anthropology of Music. Chicago: Northwestern University.

Midgley, Ruth (Managing editor). 1976. Musical Instruments of the World. New York: Facts on File, Inc.

Pekei, Titus. 2013. Cermin Noken Papua: Perspektif Kearifan Mata Budaya Papuani. Kalibobo, Nabire, Papua: Ecology Papua Institute.

Rai S., I Wayan, at.al. 2019. "Tifa From the Land of Papua: Text and Context". The Asian International Journal of Life Sciences, Vol 28 (2), July-December 2019. 
Spradley, James P. 1980. Participant Observation. Orlando: Holt, Rinehart and Winston, Inc.

Spradley, James P. 1979. The Ethnographic Interview. Orlando: Holt, Rinehart and Winston, Inc.

Silak, Ismael Roby. 2011. Konflik Perang dan Perdamaian Orang Yali di Angguruk. Makassar: Pustaka Refleksi.

Sumiarni, Endang, dkk. 2010. Hukum Adat dan Kearifan Lokal Suku Sentani. Jayapura: Biro Hukum Setda Papua.

Vansina, Jan. 2014. Tradisi Lisan Sebagai Sejarah (Penerjemah Astrid Reza, dkk). Yogyakarta: Penerbit Ombak.

Warsito, Tulus, dan Wahyuni Kartikasari. 2007. Diplomasi Kebudayaan, Konsep dan Relevansi Bagi Negara Berkembang: Studi Kasus Indonesia. Yogyakarta: Penerbit Ombak.

Woodson, Craig DeVere. 1986. The Atumpan Drum in Asante: A Study of Their Art and Technology. Ann Arbor, Michigan: University Microfilms International. 